\title{
Antioxidants, quinone reductase inducers and acetylcholinesterase inhibitors from Spondias tuberosa fruits
}

\author{
Maria Luiza Zeraik ${ }^{a}$, Emerson Ferreira Queiroz ${ }^{b, *}$, Laurence Marcourt ${ }^{b}$, \\ Olivier Ciclet ${ }^{b}$, Ian Castro-Gamboa ${ }^{a}$, Dulce Helena Siqueira Silva ${ }^{a}$, \\ Muriel Cuendet ${ }^{b}$, Vanderlan da Silva Bolzani ${ }^{a, * *}$, Jean-Luc Wolfender ${ }^{b}$ \\ a Nucleus of Bioassays, Biosynthesis and Ecophysiology of Natural Products (NuBBE), Department of Organic \\ Chemistry, Institute of Chemistry, São Paulo State University (UNESP), P. O. Box 355, 14800-900, Araraquara, \\ São Paulo, Brazil \\ b School of Pharmaceutical Sciences, University of Geneva, University of Lausanne, CH-1211 Geneva 4, \\ Switzerland
}

\section{A R T I C L E I N F O}

Article history:

Received 4 August 2015

Received in revised form 30

November 2015

Accepted 3 December 2015

Available online 8 January 2016

Keywords:

Spondias tuberosa fruits

Acetylcholinesterase inhibition

Antioxidant activity

Cancer chemopreventive activity

Quinone reductase induction

UHPLC/TOF/MS

\begin{abstract}
A B S T R A C T
The methanolic extract of umbu (Spondias tuberosa) presented high antioxidant activities in the DPPH, ABTS and ORAC assays, as well as acetylcholinesterase (AChE) inhibition activity. The dichloromethane extract exhibited cancer chemopreventive activity, with a quinone reductase induction in Hepa1c1c7 cells. The localization of the active compounds was performed by HPLC activity-based profiling, and preliminary structural information was obtained by HPLC-PAD-ESI-MS and UHPLC-TOF-HRMS. The main constituents from the methanolic extract were efficiently isolated in a single step by preparative MPLC-UV. Two new natural products were identified, together with five known compounds. The structures of the compounds were elucidated by 2D NMR and ESI-HRMS. The dichloromethane extract was fractionated by SPE and by semi-preparative HPLC-UV-ELSD. Using this approach, one anacardic acid derivative was isolated. However, this compound was not responsible for QR induction. This study highlights the potential of umbu as an active ingredient for functional food formulations.
\end{abstract}

(c) 2015 Elsevier Ltd. All rights reserved.

* Corresponding author. School of Pharmaceutical Sciences, University of Geneva, Quai Ansermet 30, 1211 Geneva 4, Switzerland. Tel.: +412237936 41; fax: +41223793399.

E-mail address: emerson.ferreira@unige.ch (E.F. Queiroz).

** Corresponding author. Nuclei for Bioassays, Biosynthesis and Ecophysiology of Natural Products (NuBBE), Department of Organic Chemistry, Institute of Chemistry, São Paulo State University (UNESP), P. O. Box 355, 14800-900, Araraquara, São Paulo, Brazil.

E-mail address: bolzaniv@iq.unesp.br (V. da Silva Bolzani).

Abbreviations: DPPH', 2.2-diphenyl-1-picrylhydrazyl free radical; ABTS ${ }^{*}, 2.2^{\prime}$-azino-bis(3-ethylbenzothiazoline-6-sulphonic acid); ORAC, oxygen radical absorbance capacity; AChE, acetylcholinesterase; QR, quinone reductase; MEM, Minimum Essential Medium; HPLC, high performance liquid chromatography; MPLC, medium pressure liquid chromatography; SPE, solid phase extraction; UHPLC, ultra-high performance liquid chromatography; TOF, time-of-flight; ESI, electrospray ionization; MS, mass spectrometry; NMR, nuclear magnetic resonance; HMBC, heteronuclear multiple-bond correlation

http://dx.doi.org/10.1016/j.jff.2015.12.009

1756-4646/@ 2015 Elsevier Ltd. All rights reserved. 


\section{Introduction}

In Brazil, a large variety of edible fruits exists since the country is one of the three largest fruit producers in the world (Maia, Sousa, Lima, Carvalho, \& Figueiredo, 2009). Tropical fruits represent an original and valuable source of bioactive compounds, and their consumption is increasing on the national and international markets due to growing recognition of their nutritional and therapeutic value (Steinmetz \& Potter, 1996; Viegas et al., 2007; Zeraik et al., 2011). Nevertheless, fruits consumed on the local Brazilian market are poorly studied for their chemical constituents, and their biological activities remain unknown. This is the case of Spondias tuberosa Arr. Camara, a native fruit popularly known as "umbu".

S. tuberosa is a tropical Anacardiaceae native to the Northeast of Brazil and plays an important role in the local economy of people living in the Caatinga ecosystem, since it blooms and bears fruits during the dry season, making this plant a valuable source of income for the local population during this period (Braga, 2001). The fruit of this species is appreciated in the North and Northeast of Brazil mainly because of its refreshing and acidic flavour. It can be consumed fresh, as a juice, ice cream, sweet, jam or as the traditional "umbuzada" (fruit pulp boiled with milk and sugar) (Cavalcanti, Resende, \& Brito, 2000).

Scientific information on this fruit is scanty. Recent studies have shown that some Brazilian fruits, including umbu, have antioxidant potential that can be attributed to the presence of phenolic compounds in the pulp (Almeida et al., 2011; Goncalves, Lajolo, \& Genovese, 2010; Rufino et al., 2010). Previous work reported the acetylcholinesterase (AChE) inhibitory properties of some Brazilian fruits by autobiography, and showed an activity in the umbu seeds (Omena et al., 2012). Vitamins and minerals have also been identified in the pulp (Narain, Bora, Holschuh, \& Vasconcelos, 1992). Recently, 37 volatile compounds found in ripe umbu fruit pulp have been described (Galvao, Narain, dos Santos, \& Nunes, 2011). However, no phytochemical study has been performed on the polar compounds present in the fruit pulp. The present study describes the isolation and structure elucidation of all major polar constituents from the methanolic and dichloromethane extracts found in the umbu fruit. This led to the identification of compounds responsible for the AChE inhibition, antioxidant and cancer chemopreventive activities of the extracts. Eight compounds were identified and two of them are new natural products.

\section{Materials and methods}

\subsection{General experimental procedures}

Optical rotations were measured in a methanolic solution on a Perkin-Elmer 241 polarimeter (Perkin-Elmer, Waltham, MA, USA), using one decimeter tube. UV spectra were measured on a Perkin-Elmer Lambda 20 spectrophotometer (Perkin-Elmer, Waltham, MA, USA). NMR spectroscopic data were recorded on a $500 \mathrm{MHz}$ Varian Inova spectrometer (Varian, Palo Alto, CA, USA). Chemical shifts are reported in parts per million $(\delta)$ using the residual DMSO- $d_{6}$ signal $\left(\delta_{\mathrm{H}} 2.50 ; \delta_{\mathrm{C}} 39.5\right)$ as internal standards for ${ }^{1} \mathrm{H}$ and ${ }^{13} \mathrm{C} \mathrm{NMR}$, and coupling constants $(J)$ are reported in Hz. Complete assignment was performed based on 2D experiments (COSY, NOESY, edited-HSQC and HMBC). ESI-HRMS data were obtained on a Micromass LCT Premier time-offlight (TOF) mass spectrometer from Waters with an electrospray ionization (ESI) interface (Waters, Milford, MA, USA). Analytical HPLC was performed using an HP 1100 system equipped with a photodiode array detector (Agilent Technologies, Santa Clara, CA, USA). Preparative medium pressure liquid chromatography (MPLC) was performed using a modular Buchi MPLC system (Flawil, Switzerland) equipped with 681 pump module C-615, UV-Vis Detector module C-640 and fraction collector module C-660 (Buchi, Flawil, Switzerland). The column $\left(460 \times 70 \mathrm{~mm}\right.$ i.d.) was loaded with ZEOprep ${ }^{\circledR} \mathrm{C}_{18}$ as the stationary phase (ZEOprep ${ }^{\circledR} C_{18}, 15-25 \mu \mathrm{m}$, Zeochem, Uetikon am See, Switzerland). Semi-preparative HPLC was performed using a Shimadzu LC-8A pump (Shimadzu, Columbia, MD, USA) equipped with a UV detector using an X-Bridge $\mathrm{C}_{18}$ column $(150 \times 21 \mathrm{~mm}$ i.d.; $5 \mu \mathrm{m})$ (Waters, Milford, MA, USA). HPLCmicrofractionation was performed with an Armen modular spot prep II (Saint-Avé, France) with an X-Bridge RP $\mathrm{C}_{18}$ column $(250 \times 10 \mathrm{~mm}$, i.d.; $5 \mu \mathrm{m})$ (Waters, Milford, MA, USA).

\subsection{Plant material}

S. tuberosa Arr. Camara (Anacardiaceae) fruits were collected in João Pessoa, Paraíba, Brazil, in January 2012 by Prof. Marçal de Queiroz Paulo from the Federal University of Paraíba (UFPB). A voucher specimen was deposited at the School of Pharmaceutical Sciences, Phytochemistry and Bioactive Natural Products Research Unit, University of Geneva ( $n^{\circ}$ 2015.001).

\subsection{Extraction}

The umbu pulp was separated from the seed and homogenized with a mixer. After this step, the pulp was frozen and lyophilised. The powdered pulp was exhaustively extracted by maceration with hexane, followed by dichloromethane and methanol. The dry extracts were obtained after removing the solvent by evaporation under reduced pressure at $40^{\circ} \mathrm{C}$.

\subsection{HPLC-UV/PDA-MS analysis}

The HPLC-UV/PDA analyses were carried out on an HP 1100 system connected to a photodiode array detector (Agilent Technologies, Santa Clara, CA, USA). The separation was performed using an $\mathrm{X}$-Bridge $\mathrm{C}_{18}$ column as the stationary phase $(250 \times 4.6 \mathrm{~mm}$ i.d.; $5.0 \mu \mathrm{m})$ supplied by Waters, Milford, MA, USA, preceded by a guard column $(20 \times 4.0 \mathrm{~mm}$ i.d.; $5.0 \mu \mathrm{m})$, containing the same stationary phase. The solvent system used was a mixture of $\mathrm{H}_{2} \mathrm{O}(\mathrm{A})$ and $\mathrm{MeOH}(\mathrm{B})$ both with $0.1 \%$ formic acid, gradient mode 5 to $100 \%$ of $B$ in 60 min, with linear gradient. The samples $(10 \mu \mathrm{g} / \mathrm{mL})$ were injected automatically $(20 \mu \mathrm{L})$, with a flow rate of $1 \mathrm{~mL} / \mathrm{min}$. The chromatogram was monitored simultaneously at 254, 280 and $366 \mathrm{~nm}$ and UV spectra of individual peaks were recorded in the range of 200-400 nm. LC-PDA-MS data were obtained with an Agilent 1100 series system consisting of an auto sampler, highpressure mixing pump and PAD detector connected to a Finnigan MAT LCQ ion trap mass spectrometer equipped with a Finnigan ESI. The LC effluent was split using a T-splitter to 
produce a flow of $0.2 \mathrm{~mL} / \mathrm{min}$. ESI-MS conditions: capillary voltage $30 \mathrm{~V}$, capillary temperature $200^{\circ} \mathrm{C}$, source voltage $4.5 \mathrm{kV}$, source current $80 \mu \mathrm{A}$, nitrogen as sheath gas flow, negative ion mode.

\subsection{HPLC-TOF-HRMS analyses}

High resolution mass spectrometry (HRMS) metabolite profiling of the extracts was performed on a Micromass-LCT Premier Time of Flight (TOF) mass spectrometer (Waters, Milford, MA, USA) equipped with an electrospray interface and coupled to an Acquity UPLC system (Waters, Milford, MA, USA). The ESI conditions were as follows: capillary voltage $2800 \mathrm{~V}$, cone voltage $40 \mathrm{~V}, \mathrm{MCP}$ detector voltage $2400 \mathrm{~V}$, source temperature $120^{\circ} \mathrm{C}$, desolvation temperature $350^{\circ} \mathrm{C}$, cone gas flow $20 \mathrm{~L} / \mathrm{h}$, and desolvation gas flow $800 \mathrm{~L} / \mathrm{h}$. Detection was performed in positive ion mode (PI) with a $\mathrm{m} / \mathrm{z}$ range of $100-1000 \mu \mathrm{ma}$ and a scan time of $0.5 \mathrm{~s}$ in the $\mathrm{W}$-mode. The MS was calibrated using sodium formate. Leucine-enkephalin (Sigma-Aldrich, Steinheim, Germany) was used as an internal reference at $2 \mu \mathrm{g} / \mathrm{mL}$ and infused through a Lock Spray ${ }^{\mathrm{TM}}$ probe at a flow rate of $10 \mu \mathrm{L} / \mathrm{min}$ with the help of a second LC pump. The separation was performed on a $B E H C_{18}$ UPLC column $(50 \times 2.1 \mathrm{~mm}$ i.d.; $1.7 \mu \mathrm{m}$, Waters). The solvent system used was (A) MeCN containing $0.01 \%$ formic acid and (B) $\mathrm{H}_{2} \mathrm{O}$ containing $0.01 \%$ formic acid; step gradient: 5 to $36 \%$ B in $1 \mathrm{~min}$, then $36 \%$ B to $36 \%$ B in $2 \mathrm{~min}$, $36 \% \mathrm{~B}$ to $95 \% \mathrm{~B}$ in $1.5 \mathrm{~min}$; flow rate $1.1 \mathrm{~mL} / \mathrm{min})$. The temperature was set to $40{ }^{\circ} \mathrm{C}$. The injected volume was kept constant $(1 \mu \mathrm{L})$.

\subsection{Semi-preparative HPLC-UV microfractionation of the methanolic crude extract}

The microfractionation of the methanolic extract of umbu pulp was performed with an Armen modular Spot Prep II system (Saint-Avé, France), with an X-Bridge $C_{18}$ column $(250 \times 10 \mathrm{~mm}$, i.d., $5 \mu \mathrm{m}$, Waters). The solvent system used was a mixture of $\mathrm{H}_{2} \mathrm{O}(\mathrm{A})$ and $\mathrm{MeOH}(\mathrm{B})$ both with $0.1 \%$ formic acid, gradient mode 5 to $100 \%$ of $\mathrm{B}$ in $60 \mathrm{~min}$, with linear gradient. The flow rate was $2 \mathrm{~mL} / \mathrm{min}$ and the injection volume was $200 \mu \mathrm{L}(10 \mathrm{mg}$ of the extract). To localize the biological activity and to generate enough material, fractions were collected every $10 \mathrm{~mL}$. After collection, each fraction was concentrated using a rotary evaporator and then dried using $\mathrm{N}_{2}$. The separation yielded 10 fractions; these were analysed by HPLC-PAD under the same conditions used for the fruit extract analysis. Each fraction was evaluated for antioxidant activity and AChE inhibition.

\subsection{Solid phase extraction (SPE) fractionation of dichloromethane crude extract}

The fractionation of the dichloromethane extract of umbu pulp was performed with an SPE system, with $\mathrm{C}_{18}$ column. The solvent system used was a mixture of $\mathrm{H}_{2} \mathrm{O}(\mathrm{A})$ and $\mathrm{MeOH}(\mathrm{B})$, in the following ratios: 20:80, 40:60, 60:40, 80:20, 100:0. The flow rate was $1 \mathrm{~mL} / \mathrm{min}$ and the injection volume was $5 \mathrm{~mL}$. The separation yielded 5 fractions, which were analysed by HPLCUV/PAD under the same conditions used for the fruit extract analysis. Each fraction was evaluated for the induction of quinone reductase to localize the active region.

\subsection{Isolation of compounds present in the methanolic and dichloromethane extracts}

The methanolic extract was fractionated $(1.8 \mathrm{~g})$ using a modular MPLC system equipped with 681 pump module C-615, UVVis detector module C-640, fraction collector module C-660 (Buchi, Flawil, Switzerland), and a column loaded with ZEOprep ${ }^{\circledR}$ $\mathrm{C}_{18}$ as the stationary $(460 \mathrm{~mm} \times 70 \mathrm{~mm}$ i.d.; $25 \mu \mathrm{m}$ ) (Zeochem, Uetikon am See, Switzerland). The mobile phase used was $\mathrm{MeOH}$ and $\mathrm{H}_{2} \mathrm{O}$ containing $0.1 \%$ formic acid, with optimized elution gradient mode 5 to $30 \%$ of B in $8.5 \mathrm{~h}$, isocratic step of $30 \%$ of $\mathrm{B}$ during $11.9 \mathrm{~h}, 30$ to $80 \%$ in $43.8 \mathrm{~h}$. Flow rate was $4.0 \mathrm{~mL} / \mathrm{min}$, and the UV absorbance was detected at $254 \mathrm{~nm}$. The MPLC yielded 250 fractions. Each 250 MPLC fraction was profiled with high throughput UHPLC-TOF-MS. The fractions were grouped according to the UV and TIC MS profiles. Fraction 23 yielded 1 (6.0 mg), fractions $25-27$ yielded a mixture of 2 and 3 (13.7 mg), fractions 29-31 yielded 4 (26.0 mg), fractions 44-49 yielded 5 (350.4 mg), fractions $72-$ 73 yielded 6 (13.8 $\mathrm{mg}$ ) and fractions 180-181 yielded 7 (7.4 mg) (Fig. 1).

The dichloromethane extract was fractionated (100 mg) using a semi-preparative HPLC-UV-ELSD Armen modular spot Prep II, with a normal phase column loaded with silica gel as the stationary phase $(460 \mathrm{~mm} \times 70 \mathrm{~mm}$ i.d.; $25 \mu \mathrm{m})$. The mobile phase used was hexane (A) and ethyl acetate (B), with optimized elution gradient mode: 2 to $5 \%$ of B in $10 \mathrm{~min}, 5$ to $10 \%$ of B in $25 \mathrm{~min}, 10 \%$ of B for $30 \mathrm{~min}, 10-15 \%$ of B in $40 \mathrm{~min}, 15$ to $60 \%$ of $B$ in $70 \mathrm{~min}$. Flow rate was $5.0 \mathrm{~mL} / \mathrm{min}$, injection volume was $10 \mathrm{~mL}$, and the UV absorbance was detected at $254 \mathrm{~nm}$. To localize the biologically active compounds, the fractions were collected every $10 \mathrm{~mL}$. The HPLC-UV-ELSD yielded 40 fractions. Fractions 9-10 yielded an anacardic acid derivative (8) (Fig. 1).

\subsubsection{Compound identification}

2.8.1.1. Compound 1. Amorphous powder; $[\alpha]_{\mathrm{D}}^{25} 17.5(c=0.1$, $\mathrm{MeOH}) ; \mathrm{UV}(\mathrm{MeOH}) \lambda_{\max }(\log \varepsilon) \mathrm{nm}: 274$ (1.04). ${ }^{1} \mathrm{H}$ NMR (DMSO$\left.\mathrm{d}_{6}, 500 \mathrm{MHz}\right) \delta 2.52(2 \mathrm{H}, \mathrm{t}, J=7.8 \mathrm{~Hz} ; \mathrm{H}-7), 3.16\left(1 \mathrm{H}, \mathrm{m}, \mathrm{H}-4^{\prime}\right)$, 3.24-3.28 (3H, m, H-2', 3', 5'), 3.48 (1H, m, H-6'a), 3.51 (2H, t, $J=7.8 \mathrm{~Hz} ; \mathrm{H}-8), 3.69$ (1H, m, H-6'b), 4.57 (1H, d, J=6.5 Hz, H-1'), $6.33(1 \mathrm{H}, \mathrm{d}, J=2.0 \mathrm{~Hz}, \mathrm{H}-6), 6.45(1 \mathrm{H}, \mathrm{d}, \mathrm{J}=2.0 \mathrm{~Hz}, \mathrm{H}-2) ;{ }^{13} \mathrm{C} \mathrm{NMR}$ (DMSO- $d_{6}, 125 \mathrm{MHz}$ ) $\delta 38.8$ (C-7), 62.4 (C-8), 60.8 (C-6'), 69.8 (C$\left.4^{\prime}\right), 73.4$ (C-2'), 75.9 (C-3'), 77.2 (C-5'), 102.8 (C-1'), 108.5 (C-2), 111.1 (C-6), 129.3(C-1), 133.2 (C-4), 145.4 (C-5), 145.9 (C-3); LC-ESI$\mathrm{MS}^{\mathrm{n}}$ m/z 331.06 [M-H]-, 169.03 [M-H-162]-. ESI-HRMS m/z: 331.0973 $[\mathrm{M}-\mathrm{H}]^{-}$(calcd for $\mathrm{C}_{14} \mathrm{H}_{20} \mathrm{O}_{9}, 332.1107, \Delta \mathrm{ppm}=4$ ).

2.8.1.2. Compound 4. Amorphous powder; $[\alpha]_{D}^{25} 20.4(c=0.1$, $\mathrm{MeOH}) ; \mathrm{UV}(\mathrm{MeOH}) \lambda_{\max }(\log \varepsilon) \mathrm{nm}: 258$ (sh) (1.44), 294 (1.04); ${ }^{1} \mathrm{H}$ NMR (DMSO- $\left.d_{6}, 500 \mathrm{MHz}\right) \delta 3.20-3.24\left(2 \mathrm{H}, \mathrm{m}, \mathrm{H}-3^{\prime}, 4^{\prime}\right), 3.25$ (1H, m, H-2'), 3.29 (1H, m H-5'), 3.51 (1H, dd, J = 11.5, 3.8 Hz, H-6'b), $3.65\left(1 \mathrm{H}, \mathrm{d}, J=11.5 \mathrm{~Hz}, \mathrm{H}-6^{\prime} \mathrm{a}\right), 3.75\left(3 \mathrm{H}, \mathrm{s}, \mathrm{OCH}_{3}\right), 4.87(1 \mathrm{H}, \mathrm{d}$, $J=7.3 \mathrm{~Hz}, \mathrm{H}-1^{\prime}$ ), 7.12 (1H, s, H-2), 7.15 (1H, s, H-6); ${ }^{13} \mathrm{C}$ NMR (DMSO$\left.d_{6}, 125 \mathrm{MHz}\right) \delta 60.1\left(\mathrm{OCH}_{3}\right), 60.5\left(\mathrm{C}-6^{\prime}\right), 69.5\left(\mathrm{C}-4^{\prime}\right), 73.4\left(\mathrm{C}-2^{\prime}\right), 76.7$ (C-5'), 77.0 (C-3'), 101.2 (C-1'), 108.3 (C-2), 111.5 (C-6), 139.6 (C4), 149.9 (C-5), 150.4 (C-3), 168.5 (C-7);LC-ESI-MS ${ }^{n}$ m/z 345.0 [M$\mathrm{H}]^{-}, 183.0$ [M-H-162] $]^{-}$; ESI-HRMS m/z: 345.0997 [M-H] $]^{-}$(calcd for $\mathrm{C}_{14} \mathrm{H}_{18} \mathrm{O}_{10}, 346.0900, \Delta \mathrm{ppm}=2.8$ ). 
<smiles>OCCc1cc(O)c(O)c(OC2OCC(O)C(O)C(O)C2O)c1</smiles><smiles>COC(=O)c1cc(O)c(OC)c(OC2OCC(O)C(O)C(O)C2O)c1</smiles><smiles>CCCC/C=C/CCCCCCCCCc1cccc(O)c1C(=O)O</smiles>

8<smiles>O=C(O)c1cc(O)c(O)c(O)c1</smiles>

2<smiles>COC(=O)c1cc(O)c(OC)c(O)c1</smiles>

6<smiles>COc1cc(O)ccc1OC1O[C@H]2CO[C@H](Oc3cc(C(=O)O)cc(O)c3OC)[C@H](O1)C(O)C(O)C2O</smiles>

4<smiles>COc1cc(O)c2c(c1)OC(c1ccc(O)c(OC3OCC(O)C(O)C(O)C3O)c1)CC2=O</smiles>

Fig. 1 - Structures of the isolated compounds from the pulp of Spondias tuberosa.

\subsection{Enzymatic hydrolysis}

Hydrolysis was performed on 1 and 4 to determine the nature of the hexose (Polasek et al., 2013). The reaction was carried out on $0.5 \mathrm{mg}$ of compound 1 or 4 , once with 28 units of $\beta$-glucosidase from almonds and once with 28 units of $\beta$-galactosidase from Escherichia coli, both supplied by SigmaAldrich Chemical Co. The samples were dissolved in $5.0 \mathrm{~mL}$ of acetate buffer $(\mathrm{pH}=5)$ and incubated under agitation at $37^{\circ} \mathrm{C}$ for $48 \mathrm{~h}$. The products of hydrolysis were then compared on a TLC plate with compounds 1 and 4. TLC eluent: $\mathrm{CHCl}_{3}-\mathrm{MeOH}-\mathrm{H}_{2} \mathrm{O}$ (65:35:5). TLC support: Merck silica gel 60 F254 aluminium. Detection on UV, $\Lambda=254 \mathrm{~nm}$.

\subsection{Biological assays}

\subsubsection{Antioxidant activity assays}

2.10.1.1. $\mathrm{DPPH}^{*}$ scavenging capacity assay. The radical scavenging capacity of the compounds isolated from the methanolic extract and of the positive control (quercetin) was evaluated from their ability to reduce the radical 2,2-diphenyl-1picrylhydrazyl $\left(\mathrm{DPPH}^{\circ}\right)$. The $\mathrm{DPPH}^{*}$ assay was carried out according to the procedure described by Brandwilliams, Cuvelier, and Berset (1995) with some modifications (Ancerewicz et al., 1998). An aliquot of $250 \mu \mathrm{L}$ of $\mathrm{DPPH}^{*}$ ethanolic solution $\left(1 \times 10^{-4} \mathrm{~mol} / \mathrm{L}\right)$ was added to $35 \mu \mathrm{L}$ of compounds $1-7$ at various concentrations $(72.00-1.12 \mathrm{mg} / \mathrm{mL}$, in ethanol). The same procedure was carried out with ethanolic solutions of quercetin. The decrease in absorbance of the resultant solution at $515 \mathrm{~nm}$ was monitored at $1 \mathrm{~min}$ intervals for $90 \mathrm{~min}$, using a microplate spectrophotometer (Synergy 2 Multi-Mode, BioTek, USA). The microplate was automatically shaken prior to each reading. The ethanolic solution of $\mathrm{DPPH}^{\bullet}\left(250 \mu \mathrm{L} ; 1 \times 10^{-4} \mathrm{~mol} / \mathrm{L}\right)$ was used as control. The percentage of scavenged DPPH ${ }^{*}$ was calculated using the absorbance value after $90 \mathrm{~min}$, with the following equation: \% DPPH ${ }^{*}$ scavenging $=\left[\mathrm{Abs}_{515 \mathrm{~nm}}\right.$ (control) $-\mathrm{Abs}_{515 \mathrm{~nm}}$ (sample)/Abs $515 \mathrm{~nm}$ (control)] $\times 100$. The radical scavenging capacity was expressed in terms of EC $_{50}$ (amount of antioxidant necessary to decrease the initial concentration of $\mathrm{DPPH}^{\bullet}$ by $50 \%$ ). The $\mathrm{EC}_{50}$ was calculated graphically using an analytical curve in the linear range by plotting the isolated compounds us. the corresponding scavenging effect (DPPH${ }^{*}$ scavenging \%). Three independent experiments were performed in triplicate.

2.10.1.2. ABTS $^{\bullet+}$ scavenging capacity assay. The ABTS $(2,20-$ azino-bis(3-ethylbenzthiazoline-6-sulphonic acid) assay was based on a method described by Re et al. (1999) with minor modifications. ABTS was dissolved in water to obtain a $10 \mathrm{mmol} / \mathrm{L}$ stock solution. ABTS radical cation (ABTS ${ }^{\bullet+}$ ) was produced by reacting $1 \mathrm{~mL}$ of $\mathrm{ABTS}^{\circ+}$ stock solution with $430 \mu \mathrm{L}$ of potassium persulphate $(8.17 \mathrm{mmol} / \mathrm{L})$. The mixture was shaken and kept in the dark at room temperature for $16 \mathrm{~h}$. This solution was diluted with water 60 times for the assay. Then, $250 \mu \mathrm{L}$ of diluted ABTS $^{*+}$ solution was added to $35 \mu \mathrm{L}$ of compounds $1-7$ at various concentrations $(36.00-0.56 \mathrm{mg} / \mathrm{mL}$, in ethanol) in 96-well plates. The absorbance at $755 \mathrm{~nm}$ was recorded at $1 \mathrm{~min}$ intervals for $90 \mathrm{~min}$, using a microplate spectrophotometer (Synergy 2 Multi-Mode). The microplate was automatically shaken prior to each reading. The diluted ABTS $^{\circ+}$ solution was used as control. The percentage of scavenged ABTS was calculated as follows: \% $\mathrm{ABTS}^{\bullet+}$ scavenging $=\left[\mathrm{Abs}_{755 \mathrm{~nm}}\right.$ (control) $-\mathrm{Abs}_{755 \mathrm{~nm}}$ (sample)/Abs ${ }_{755 \mathrm{~nm}}$ (control) $\times 100$. The ABTS $^{*+}$ scavenging capacity of the standard and compounds 1-7 was expressed in terms of $\mathrm{EC}_{50}$. Quercetin was used as positive control. Three independent experiments were performed in triplicate. 
2.10.1.3. Oxygen radical absorbance capacity (ORAC) assay. The ORAC method reported by Huang, Ou, Hampsch-Woodill, Flanagan, and Prior (2002) with some modifications was used to evaluate the antioxidant capacity of compounds 1-7. AAPH (2,2'-azobis-(2-amidinopropane) dihydrochloride) reagent solution $(88 \mathrm{mmol} / \mathrm{L})$ was prepared in glycine buffer ( $\mathrm{pH}$ 8.3). A fluorescein stock solution $\left(1 \times 10^{-4} \mathrm{~mol} / \mathrm{L}\right)$ was made in glycine buffer ( $\mathrm{pH} 8.3$ ) and kept at $4{ }^{\circ} \mathrm{C}$ in the dark. A fresh fluorescein working solution $\left(6.45 \times 10^{-8} \mathrm{~mol} / \mathrm{L}\right)$ was made daily by further diluting the stock solution in glycine buffer ( $\mathrm{pH}$ 8.3). In black-walled 96-well plates, $186 \mu \mathrm{L}$ of fluorescein solution was added to $4 \mu \mathrm{L}$ of compounds $1-7$ at various concentrations $(2.50-0.08 \mathrm{mg} / \mathrm{mL}$, in glycine buffer, $\mathrm{pH}$ 8.3). The plate was covered with a lid and incubated under shaking for $15 \mathrm{~min}$ at $40{ }^{\circ} \mathrm{C}$. After this step, the reaction was initiated with $10 \mu \mathrm{L}$ of AAPH solution $(88 \mathrm{mmol} / \mathrm{L})$. The reaction was further incubated under shaking for $95 \mathrm{~min}$ at $40{ }^{\circ} \mathrm{C}$. After the incubation, the plate was kept at room temperature during 5 min to cool down, and the fluorescence was measured on a microplate reader (Synergy HT multidetection microplate reader, BioTek), set with an excitation filter at $485 \mathrm{~nm}$ and an emission filter at $528 \mathrm{~nm}$. Final fluorescence measurements were expressed relative to the control reading. For control assays, the tested compounds were replaced by a corresponding volume of glycine buffer ( $\mathrm{pH}$ 8.3) under identical conditions (value considered to be $100 \%$ ). The oxygen radical absorbance capacity of 1-7 was expressed in terms of $\mathrm{EC}_{50}$. Quercetin was used as positive control. Three independent experiments were performed in triplicate.

\subsubsection{Acetylcholinesterase activity assay}

The AChE inhibitory activity of compounds 1-7 was evaluated using the method of Ellman (Ellman, Courtney, Andres, \& Featherstone, 1961) with some modification (Di Giovanni et al., 2008). This method is based on the amount of thiocholine released when the enzyme AChE hydrolyses the substrate acetylthiocholine iodide (ATCI). The product thiocholine reacts with Ellman's reagent (5,5-bisdithionitrobenzoic acid-DTNB) to produce a yellow compound (5-thio-2-nitrobenzoate), which can be detected at $412 \mathrm{~nm}$ (Houghton, Ren, \& Howes, 2006). Fourteen microlitres of compounds 1-7 (final concentrations ranging from 40.00 to $0.04 \mu \mathrm{mol} / \mathrm{L}$ ) were added to $10 \mu \mathrm{L}$ substrate in water (final concentration of $0.44 \mathrm{mmol} / \mathrm{L}$ ) and $106 \mu \mathrm{L}$ Ellman's reagent $(0.15 \mathrm{~mol} / \mathrm{L}$ in $0.1 \mathrm{~mol} / \mathrm{L}$ phosphate buffer $\mathrm{pH} 7.4)$ in a 96-well plate. Then, an aliquot of $10 \mu \mathrm{L}$ AChE solution from Electrophorus electricus (Sigma-Aldrich Chemical, St. Louis, MO, USA) $1.0 \mathrm{U} / \mathrm{mL}$ in $0.1 \mathrm{~mol} / \mathrm{L}$ phosphate buffer $\mathrm{pH} 7.4$, containing human serum albumin at $1 \mathrm{mg} / \mathrm{mL}$ was added to initiate the enzymatic reaction. The absorbance of the product was measured at $412 \mathrm{~nm}$ after $6 \mathrm{~min}$ incubation using a microplate reader (PowerWaveX, BioTek). Stock solutions of tested compounds and positive controls (tacrine and galantamine) were prepared in DMSO and diluted in phosphate buffer $\mathrm{pH}$ 7.4, resulting in a final concentration of $1 \%$ DMSO in each well. Three independent experiments were performed in triplicate. For control assays (blanks), the tested compounds were replaced by the corresponding volume of DMSO, under identical conditions (value considered to be $100 \%$ ). The percent inhibition was calculated using the formula: $\%$ AChE inhibition $=\left[\mathrm{Abs}_{412 \mathrm{~nm}}\right.$ (control) $-\mathrm{Abs}_{412 \mathrm{~nm}}($ sample)/Abs $412 \mathrm{~nm}$ (control)] $\times 100$. The $50 \%$ inhibitory concentration ( $\mathrm{IC}_{50}$ ) was calculated graphically from a dose-response curve constructed with at least 6 different concentrations and obtained by plotting the percentage of inhibition versus concentration using the GraphPad Prism 5.0 software. Three independent experiments were performed in triplicate.

\subsubsection{Cancer chemopreventive activity assay}

2.10.3.1. Cell culture conditions. Hepa1c1c7 cells (American Type Culture Collection (ATCC), Rockville, MD) were cultured in $\alpha$-modified Minimum Essential Medium containing $2 \mathrm{mM}$ glutamine (Life Technologies, Zug, Switzerland), supplemented with $10 \%$ foetal calf serum, penicillin $\mathrm{G}(100 \mathrm{U} / \mathrm{mL})$ and streptomy$\operatorname{cin}(100 \mu \mathrm{g} / \mathrm{mL})$ at $37{ }^{\circ} \mathrm{C}$ in a humidified atmosphere of $5 \% \mathrm{CO}_{2}$ in air, according to ATCC recommendations.

2.10.3.2. Induction of quinone reductase (QR) activity. Hepa1c1c7 cells were plated in 96-well microtitre plates at a density of 2000 cells/well in $100 \mu \mathrm{L}$ of medium for $24 \mathrm{~h}$. The medium was replaced by $200 \mu \mathrm{L}$ of medium containing test compounds and then incubation continued for an additional $48 \mathrm{~h}$. Control samples were composed of medium with the same concentrations of DMSO (0.5\%) and the absence of test compounds. QR activity was measured as described by Kang and Pezzuto (2004). Cells were lysed and the NADPH-dependent menadiolmediated reduction of 3-(4,5-dimethylthiazo-2-yl)-2,5diphenyltetrazolium bromide (MTT) to the corresponding blue formazan was measured on a ELx808 microplate spectrophotometer (BioTek) at $595 \mathrm{~nm}$. In parallel, the amount of viable cells was determined by protein quantification using crystal violet staining and measurement of the absorption at $595 \mathrm{~nm}$.

\section{Results and discussion}

\subsection{Phytochemical analyses of the methanolic extract of the umbu pulp}

In the frame of a screening of various fruit extracts, significant antioxidant and AChE inhibitory properties were recorded for the methanolic extract of the umbu pulp. High antioxidant activities were measured in the DPPH ${ }^{*}(89 \%)$, ABTS $^{*+}(97 \%)$ and ORAC (64\%) assays at $40 \mu \mathrm{g} / \mathrm{mL}$. At the same concentration, the extract inhibited $61 \%$ AChE activity. To localize the compounds responsible for the AChE inhibition, the crude extract was microfractionated by reversed phase semipreparative HPLC in ten main fractions. The AChE inhibition was associated with fractions 2 and 5 , while all of the other fractions were inactive (Fig. 2A). Dereplication of the active compounds by HPLC-PAD-ESI-MS and UHPLC-TOF-MS (Fig. 2) revealed that all UV active metabolites were polyphenol derivatives (Alonso-Salces et al., 2004; Arapitsas, 2012). However, the UV and MS data were not sufficient for their unambiguous identification. The extract was fractionated at large scale using reversed phase MPLC-UV for a complete identification of these compounds and for a detailed assessment of their biological activities. 

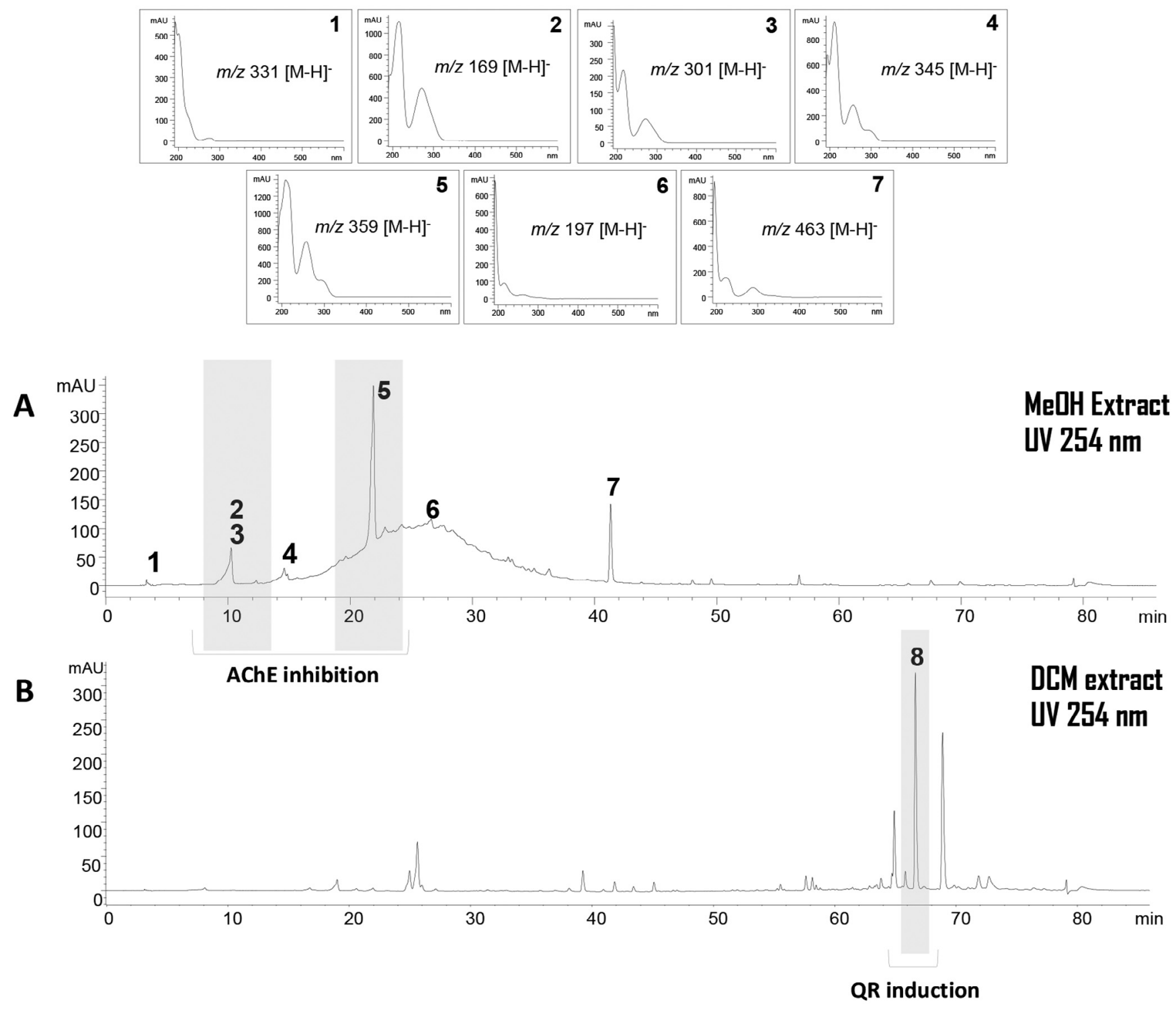

Fig. 2 - HPLC-UV/PAD-ESI-MS (negative mode) analysis of the methanolic (A) and dichloromethane (B) extracts of the pulp of Spondias tuberosa. Zones with AChE inhibition and QR induction are highlighted.

\subsection{Isolation of the active compounds from the} methanolic extract by MPLC-UV

To achieve efficient one step MPLC-UV isolation, the separation conditions were optimized at the analytical level using HPLC-UV/PAD with a reversed phase column packed with the same stationary phase as the MPLC $\left(\mathrm{C}_{18}\right.$ Zeoprep $\left.{ }^{\circledR}\right)$. These analytical gradient elution conditions were geometrically transferred to MPLC-UV by chromatographic calculations (Challal et al., 2015). Based on the column geometry chosen, $1.8 \mathrm{~g}$ of the umbu methanolic extract was fractioned at once. A total of 250 MPLC fractions were obtained. Aliquots were used for post-chromatographic MS detection and profiled with high throughput UHPLC-TOF-MS. This procedure yielded seven pure compounds in a single step. The structure elucidation of the compounds was performed based on 2D NMR and HRMS analyses. They were identified as gallic acid (2) (Mammela, Savolainen, Lindroos, Kangas, \& Vartiainen, 2000), isotachioside
(3) (Choi et al., 2013), 4-methoxyl-5-hydroxymethyl 3-O- $\beta$-Dglucopyranoside benzoic acid (5) (Ding et al., 2010), 3,5dihydroxy-4-methoxy benzoic acid methyl ester (6) (Arisawa et al., 1991), and eriodictyol 7-0-methylether 3'-O- $\beta$-Dglucopyranoside (7) (Wada et al., 1986) (Fig. 1). Among the known compounds, the MPLC separation afforded two new natural products (1 and 4).

Compound 1 was isolated as a brown amorphous solid powder. ESI-HRMS showed a molecular ion at m/z 331.0973 [M$\mathrm{H}]^{-}$, which is in agreement with the molecular formula $\mathrm{C}_{14} \mathrm{H}_{19} \mathrm{O}_{9}$ (calc. for $\mathrm{C}_{14} \mathrm{H}_{20} \mathrm{O}_{9}, 332.1107$ ). The ${ }^{1} \mathrm{H}$ NMR spectrum displayed two signals at $\delta_{\mathrm{H}} 6.33(1 \mathrm{H}, \mathrm{d}, J=2.0 \mathrm{~Hz}, \mathrm{H}-6)$ and $6.45(1 \mathrm{H}, \mathrm{d}$, $J=2.0 \mathrm{~Hz}, \mathrm{H}-2$ ) corresponding to two meta aromatic protons, two signals at $\delta_{\mathrm{H}} 2.52(2 \mathrm{H}, \mathrm{t}, J=7.8 \mathrm{~Hz}, \mathrm{H}-7)$ and $3.51(2 \mathrm{H}, \mathrm{t}, J=7.8 \mathrm{~Hz}$, $\mathrm{H}-8)$ assigned to two methylene groups and a doublet at $\delta_{\mathrm{H}} 4.57$ $\left(1 \mathrm{H}, \mathrm{d}, J=6.5 \mathrm{~Hz}, \mathrm{H}-1^{\prime}\right)$ together with six others proton signals between $\delta_{\mathrm{H}} 3.24$ and 3.48 suggesting the presence of a sugar moiety. This was confirmed by the MS/MS spectrum which 
displayed a fragment ion at $\mathrm{m} / \mathrm{z} 169.03[\mathrm{M}-\mathrm{H}-162]^{+}$corresponding to the loss of one hexose. The carbon chemical shift of the methylene at $\delta_{\mathrm{H}} 3.51\left(\delta_{\mathrm{C}} 62.4\right)$ indicated the presence of a terminal hydroxyl group in the ethyl chain. The HMBC correlations between the methylene protons at $\delta_{\mathrm{H}} 2.52$ and the carbons at $\delta_{\mathrm{C}} 129.3$ (C-1), 108.5 (C-2) and 111.1 (C-6) indicated the attachment of the ethyl chain to the phenyl ring. Three oxygenated aromatic carbons at $\delta_{\mathrm{C}} 133.2,145.4$ and 145.9 were detected in the HMBC spectrum via the correlations with the aromatic protons at $\delta_{\mathrm{H}} 6.33$ and 6.45. Finally, the correlation between the anomeric proton at $\delta_{\mathrm{H}} 4.57\left(\mathrm{H}-1^{\prime}\right)$ and the carbon at $\delta_{\mathrm{C}} 145.9$ (C3) proved that the sugar was attached to C-3. This was also confirmed by the NOE correlation between $\mathrm{H}-2$ and $\mathrm{H}-\mathrm{1}^{\prime}$. To identify the hexose moiety, two different enzymatic hydrolyses were undertaken using $\beta$-D-glucosidase and $\beta$-D-galactosidase, and the products were analysed by TLC (Polasek et al., 2013). The enzymatic hydrolysis only occurred with the $\beta$-D-glucosidase and confirmed the presence of a $\beta$-Dglucose. Based on these results, 1 was identified as 3,4dihydroxyphenylethanol-5- $\beta$-D-glucose, which is a new phenylethanol derivative.

Compound 4 was isolated as a brown amorphous solid powder. The ESI-HRMS spectrum showed a molecular ion at $\mathrm{m} / \mathrm{z} 345.0997[\mathrm{M}-\mathrm{H}]^{-}$, which is in agreement with the molecular formula $\mathrm{C}_{14} \mathrm{H}_{17} \mathrm{O}_{10}$ (calc. for $\mathrm{C}_{14} \mathrm{H}_{18} \mathrm{O}_{10}, 346.0900$ ). The ${ }^{1} \mathrm{H}$ NMR spectrum displayed signals of two broad singlets at $\delta_{\mathrm{H}} 7.12(\mathrm{H}-$ 6) and $7.15(\mathrm{H}-2)$ assigned to two aromatic protons, and one singlet at $\delta_{\mathrm{H}} 3.75$ assigned to a methoxyl group. As for 1 , the presence of a sugar moiety was suggested by the doublet at $\delta_{\mathrm{H}} 4.87\left(1 \mathrm{H}, \mathrm{d}, \mathrm{J}=7.3 \mathrm{~Hz}, \mathrm{H}-1^{\prime}\right)$, a series of proton signals between $\delta_{\mathrm{H}} 3.20$ and 3.65, and the neutral loss of 162 in MS/MS. In HMBC, the correlations between the two aromatic protons $(\mathrm{H}-2 / 6)$ and three oxygenated aromatic carbons at $\delta_{\mathrm{C}} 139.6$ (C-4), 149.9 (C5) and 150.4 (C-3), as well as a carbon at $\delta_{\mathrm{C}} 168.5$ suggested the presence of an acid group attached to the phenolic ring in position C-1. As for 1 , the presence of a $\beta$-D-glucose was confirmed by the enzymatic hydrolyses. The attachment of the sugar moiety at C-3 was proven by the HMBC correlation between the anomeric protons at $\delta_{\mathrm{H}} 4.87$ and the carbon signal at $\delta_{\mathrm{C}} 150.3$, as well as from the NOE between $\mathrm{H}^{\prime} \mathrm{1}^{\prime}$ and $\mathrm{H}-2$. The methoxyl group was positioned at C-4 $\left(\delta_{\mathrm{C}} 139.6\right)$ based on the HMBC correlations from this carbon to the methoxyl and the two aromatic protons $\mathrm{H}-2$ and $\mathrm{H}-6\left(\delta_{\mathrm{H}} 7.12\right.$ and 7.15 , respectively), and from the lack of NOESY correlation between the methoxyl signal and $\mathrm{H}-2 / \mathrm{H}-6$. Based on these results, 4 was identified as 5-hydroxyl, 4-methoxy-3-O- $\beta$ - $D$-glucose benzoic acid, which is a new benzoic acid derivative.

\subsection{Phytochemical analysis of the dichloromethane extract of the umbu pulp}

The dichloromethane extract exhibited significant quinone reductase induction with an induction ratio (IR) of 2.8 at $20 \mu \mathrm{g} / \mathrm{mL}$ in Hepa1c1c7 cells (Table 1). Furthermore, the viability of these cells was $78.6 \%$, proving that the extract showed very little cytotoxicity at that concentration. The methanolic extract was also tested in Hepa1c1c7 cells but no QR induction and a very low toxicity were observed (Table 1). In our search for novel plant-derived cancer chemopreventive agents, $Q R$ has been used as a biomarker of activity (Cuendet, Oteham, Moon, \& Pezzuto,
Table 1 - $Q R$ inducing activity of extracts, fractions and isolated compounds.

\begin{tabular}{lll} 
Sample & $\begin{array}{l}\mathrm{IR}^{\mathrm{b}} \text { at } \\
20 \mu \mathrm{g} / \mathrm{mL}\end{array}$ & $\begin{array}{l}\text { \% cell viability } \\
\text { at } 20 \mu \mathrm{g} / \mathrm{mL}\end{array}$ \\
\hline Dichloromethane extract & 2.8 & 78.6 \\
Methanolic extract & 1.1 & 85.0 \\
SPE 20\% & 1.7 & 85.5 \\
SPE 40\% & 1.3 & 86.3 \\
SPE 60\% & 2.9 & 56.5 \\
SPE 80\% & 3.2 & 70.7 \\
SPE 100\% & 9.1 & 26.6 \\
Compound 8 & 1.4 & 66.6 \\
\hline a 4'-Bromoflavone was used as positive control with a concentra- \\
tion that doubles the activity (CD) of 15.0 nM. \\
b IR, induction ratio. \\
\hline
\end{tabular}

2006; Giacomelli et al., 2013); many studies have shown that elevation of phase II enzymes, such as QR correlates with protection against chemical-induced carcinogenesis in animal models in the stages of initiation and promotion (Gills et al., 2006; Song et al., 1999).

To localize the compounds responsible for the cancer chemopreventive activity of the dichloromethane extract, the bioactivity-guided fractionation was performed by SPE, with $\mathrm{C}_{18}$ phase column. The fractionation yielded five main fractions, with the following ratio of $\mathrm{MeOH}: \mathrm{H}_{2} \mathrm{O}: 20: 80,40: 60,60: 40$, $80: 20,100: 0$. The fraction obtained with a ratio of $\mathrm{MeOH}: \mathrm{H}_{2} \mathrm{O}$ 80:20 was active on $\mathrm{QR}$ with low toxicity (Table 1 ), then this fraction was selected. Analyses of the active fraction were performed by semi preparative HPLC-UV-ELSD (Fig. 2B) with a normal phase column to identify the compounds responsible for the QR induction activity. The HPLC-UV-ELSD yielded 40 fractions. However, due to low yield obtained, only the major peak localized in fractions 9-10 was isolated and characterized as the anacardic acid derivative, 2-hydroxy-6-(10Z)-10-pentadecen1-yl-benzoic acid (8) (Kubo et al., 1987). The concentration needed to double the QR inducing activity of compound 8 was evaluated at $20 \mu \mathrm{g} / \mathrm{mL}(57.9 \mu \mathrm{M})$, but no activity and no toxicity were observed (Table 1$)$.

\subsection{Antioxidant and acetylcholinesterase inhibitory activity of the isolated compounds}

The antioxidant properties of the isolated compounds were evaluated by various methods (DPPH ${ }^{\circ}, \mathrm{ABTS}^{\circ+}$ and ORAC assays) to reflect multifunctional properties in both physiologically and food-related oxidative processes (Muller, Frohlich, \& Bohm, 2011). The DPPH${ }^{*}$ assay is based on the transfer of a hydrogen atom and an electron (ET), wherein $\mathrm{DPPH}^{\bullet}$ itself reacts as a radical and a probe (Brandwilliams et al., 1995). The reaction mechanisms present in the $\mathrm{ABTS}^{*+}$ assay is based only on ET (Huang et al., 2002). The ORAC assay represents a typical hydrogen atom transfer based method, since it uses a competitive reaction scheme between antioxidants and fluorescence probe (fluorescein) for a radical, usually peroxyl radical generated by $\mathrm{AAPH}$. In the DPPH${ }^{*}$ and $\mathrm{ABTS}^{*+}$ assays, the capability of each compound to scavenge an initial amount of radicals was evaluated measuring the absorbance of a solution 90 minutes after reaction and the $\mathrm{EC}_{50}$ values were determined (Table 2). Because 


\begin{tabular}{|c|c|c|c|c|}
\hline \multirow[t]{2}{*}{ Compounds } & \multicolumn{3}{|l|}{$\begin{array}{l}\mathrm{EC}_{50} \\
(\mu \mathrm{mol} / \mathrm{L})^{\mathrm{a}}\end{array}$} & \multirow{2}{*}{$\begin{array}{l}\mathrm{IC}_{50} \\
(\mu \mathrm{mol} / \mathrm{L})^{\mathrm{a}} \\
\mathrm{AChE}\end{array}$} \\
\hline & $\mathrm{DPPH}^{\bullet}$ & $\mathrm{ABTS}^{\bullet+}$ & ORAC & \\
\hline 1 & $16.08 \pm 0.25$ & $5.22 \pm 0.41$ & $1.9 \pm 0.1$ & $>40.00$ \\
\hline 2 & $3.51 \pm 0.33$ & $1.13 \pm 0.80$ & $2.9 \pm 0.2$ & $11.53 \pm 0.59$ \\
\hline 4 & $18.69 \pm 0.32$ & $9.58 \pm 0.32$ & $5.9 \pm 0.2$ & $>40.00$ \\
\hline 5 & $12.75 \pm 0.40$ & $3.83 \pm 0.40$ & $4.9 \pm 0.2$ & $12.65 \pm 0.65$ \\
\hline 6 & $9.65 \pm 0.21$ & $7.55 \pm 0.40$ & $3.4 \pm 0.2$ & $>40.00$ \\
\hline 7 & $23.66 \pm 0.21$ & $12.66 \pm 0.40$ & $4.8 \pm 0.1$ & $>40.00$ \\
\hline Quercetin ${ }^{\mathrm{b}}$ & $3.49 \pm 0.23$ & $2.97 \pm 0.40$ & $4.1 \pm 0.1$ & n.t. \\
\hline Tacrine $^{c}$ & n.t. & n.t. & n.t. & $0.09 \pm 0.02$ \\
\hline Galantamine $^{c}$ & n.t. & n.t. & n.t. & $2.40 \pm 0.25$ \\
\hline \multicolumn{5}{|c|}{$\begin{array}{l}\text { The values shown are the means } \pm \text { standard } \\
\text { from three independent experiments. } \\
\text { b Positive control for the antioxidant activity. } \\
\text { c Positive control for the AChE activity. } \\
\text { n.t.: not tested. }\end{array}$} \\
\hline
\end{tabular}

2 could not be separated from 3, but was clearly identified as gallic acid, a commercially available sample was used in the bioassays. Nevertheless, the fraction containing compounds 2 and 3 was also tested and presented high antioxidant capacity $\left(\mathrm{EC}_{50}<10 \mu \mathrm{mol} / \mathrm{L}\right)$.

Each compound tested $(1,2,4,5,6,7)$ showed high antioxidant capacity, as indicated by the $\mathrm{DPPH}^{\bullet}, \mathrm{ABTS}^{\bullet+}$ and ORAC methods (Table 2). Gallic acid showed the highest DPPH ${ }^{\bullet}$ and ABTS $^{*+}$ scavenging capacity among the compounds tested. Several studies reported the antioxidant proprieties of gallic acid and structure-activity relationship studies with this compound; the authors attributed the antioxidant activity of gallic acid to the inductive effect of the three hydroxyl groups.

The presence of functional groups on the aromatic ring as displayed by 1-7 modulates the $\mathrm{DPPH}^{*}$ and $\mathrm{ABTS}^{*+}$ reducing activities. The incorporation of carbonyl functions to the ring has a profound suppressive effect on the $\mathrm{EC}_{50}$ value. The carbonyl oxygen atom presents an electron-withdrawing effect and reduces the unpaired electron density in the conjugated systems, which leads to a higher energy of the intermediate and transition states for the reactions with radicals (Muller et al., 2011). Besides, another factor that increases substantially the antioxidant potency is the number of free hydroxyl groups present on the aromatic ring. These findings suggest that 1-7 are able to scavenge radicals, by either hydrogen or electron donating mechanisms, and can therefore act as primary antioxidants.

The capacity of compounds 1-7 to prevent the oxidative effects of radicals generated by AAPH on fluorescein was determined by the ORAC assay. One benefit of using the ORAC method is that it takes into account samples with and without lag phases of their antioxidant capacities. Because of this, the ORAC assay is often used for the determination of the antioxidant capacity of food extracts (that contain complex ingredients), combining both the inhibition time and the degree of inhibition (Cao, Alessio, \& Cutler, 1993; Huang et al., 2002). Results are presented in Table 2.

Compound 1 showed the highest antioxidant activity in the ORAC assay, with $\mathrm{EC}_{50}$ values 2 -fold higher than the standard quercetin. It was followed by $2>6>7>5>4$.
As recommended by certain research groups, the use of more than one assay to determine the antioxidant potential of food extracts or single compounds is necessary, since different methods, with different mechanisms can yield different results (Huang, Ou, \& Prior, 2005; Muller et al., 2011). Therefore, the three assays were shown to be complementary for characterizing the antioxidant property of the isolated compounds from umbu pulp.

The antioxidant values observed in the umbu extract are in the same range as those reported for some Brazilian tropical fruits such as passion fruit (Zeraik et al., 2011). However, the umbu extract presented a higher activity than some classical antioxidant extracts, such as pomegranate juice and hawthorn berries (Borges, Mullen, \& Crozier, 2010; Tadic et al., 2008).

Each purified compound was also tested in the AChE assay (Table 2). As expected from the preliminary microfractionation results (Fig. 2), gallic acid (2) and compound 5 showed high AChE inhibition, with $\mathrm{IC}_{50}$ values lower than $13 \mu \mathrm{mol} / \mathrm{L}$. On the other hand 1, 4, 6 and 7 showed no significant inhibitory effect. Previous studies indicated that gallic acid (2), previously identified in the umbu pulp, was a potent AChE inhibitor (Kulisic-Bilusic et al., 2008). To date, AChE inhibitors are still the best available option for the treatment of Alzheimer's patients, although currently used cholinesterase inhibitors, such as tacrine, produce side effects (Mukherjee, Kumar, Mal, \& Houghton, 2007). Enzymatic inhibitors presenting antioxidant properties are promising in the case of neurodegenerative diseases, due to their protective role against radical species. It is well established that oxidative modifications of endogenous cellular molecules are related to neurodegenerative disorders (Behl \& Moosmann, 2002). Studies support the hypothesis that excessive radical activity occurs in Alzheimer's disease (Valko et al., 2007), which manifests as a decrease in plasma chain-breaking antioxidants, especially vitamins A, C and E (Foy, Passmore, Vahidassr, Young, \& Lawson, 1999).

\section{Conclusions}

This work provides the first comprehensive study on the chemical composition of $S$. tuberosa fruit. The combination of HPLCUV-MS, HPLC-microfractionation and biological assays led to the localization of the active compounds directly in the crude fruit extract. An efficient isolation procedure was performed on the $\mathrm{MeOH}$ extract using a gradient transfer of analytical HPLC conditions to the preparative MPLC-UV separation. This afforded the isolation of seven compounds; among them, two are new natural products. Compounds 2 and 5 presented high antioxidant activity and acetylcholinesterase inhibition. On the other hand, the dichloromethane extract of umbu fruit showed significant $\mathrm{QR}$ inducing activity. The extract was fractionated by SPE and the active fraction was purified by semi preparative HPLC-UV-ELSD. Using this approach one anacardic acid derivative was isolated. Even if this was the main compound of the active fraction, it was not responsible for $Q R$ induction. Nevertheless, the biological activities of the crude extracts highlight the potential of umbu as a possible active ingredient for functional food products. 


\section{Acknowledgements}

The authors gratefully acknowledge Prof. Dr. Marçal de Queiroz Paulo from Paraiba Federal University (UFPB), Brazil, for the collection of S. tuberosa fruits. This work was supported by the National Research Council (CNPq) and the São Paulo Research Foundation (FAPESP), Grants 2010/52327-5, 2011/030176, 2013/07600-3, as well as the Brazilian Swiss Joint Research Programme (BSJRP), Grant 590128/2011-6 (EFQ MC, VSB, ICG, JLW). MLZ received a CNPq fellowship (Grant 240518/2012-8).

\section{R E F E R E N C E S}

Almeida, M. M. B., de Sousa, P. H. M., Arriaga, A. M. C., do Prado, G. M., Magalhaes, C. E. D., Maia, G. A., \& de Lemos, T. L. G. (2011). Bioactive compounds and antioxidant activity of fresh exotic fruits from northeastern Brazil. Food Research International, 44(7), 2155-2159.

Alonso-Salces, R. M., Ndjoko, K., Queiroz, E. F., Ioset, J. R., Hostettmann, K., Berrueta, L. A., Gallo, B., \& Vicente, F. (2004). On-line characterisation of apple polyphenols by liquid chromatography coupled with mass spectrometry and ultraviolet absorbance detection. Journal of Chromatography A, 1046(1-2), 89-100.

Ancerewicz, J., Migliavacca, E., Carrupt, P. A., Testa, B., Bree, F., Zini, R., Tillement, J. P., Labidalle, S., Guyot, D., ChauvetMonges, A. M., Crevat, A., \& Le Ridant, A. (1998). Structureproperty relationships of trimetazidine derivatives and model compounds as potential antioxidants. Free Radical Biology and Medicine, 25(1), 113-120.

Arapitsas, P. (2012). Hydrolyzable tannin analysis in food. Food Chemistry, 135(3), 1708-1717.

Arisawa, M., Hayashi, T., Shimizu, M., Morita, N., Bai, H., Kuze, S., \& Ito, Y. (1991). Isolation and cytotoxicity of two new flavonoids from Chrysosplenium grayanum and related flavonols. Journal of Natural Products, 54(3), 898-901.

Behl, C., \& Moosmann, B. (2002). Antioxidant neuroprotection in Alzheimer's disease as preventive and therapeutic approach. Free Radical Biology and Medicine, 33(2), 182-191.

Borges, G., Mullen, W., \& Crozier, A. (2010). Comparison of the polyphenolic composition and antioxidant activity of European commercial fruit juices. Food \& Function, 1(1), 73-83.

Braga, R. (2001). Plantas do nordeste, especialmente do ceará. Natal: Fundação Guimarães Duque. Coleção Mossoroense.

Brand-Williams, W., Cuvelier, M. E., \& Berset, C. (1995). Use of a free-radical method to evaluate antioxidant activity. Food Science and Technology-Lebensmittel-Wissenschaft \& Technologie, 28(1), 25-30.

Cao, G., Alessio, H. M., \& Cutler, R. G. (1993). Oxygen-radical absorbance capacity assay for antioxidants. Free Radical and Biology Medicine, 14, 303-311.

Cavalcanti, N. B., Resende, G. M., \& Brito, L. T. L. (2000). Processamento do fruto de imbuzeiro (Spondias tuberosa. Arr. Cam.). Ciência e Agrotecnologia, 24, 252-259.

Challal, S., Queiroz, E. F., Kloeti, W., Debrus, B., Guillarme, D., \& Wolfender, J. L. (2015). Rational and efficient preparative isolation of natural products by MPLC-UV-ELSD based on HPLC to MPLC gradient transfer. Planta Medica, 81(17), 16361643.

Choi, H. G., Lee, H. D., Kim, S. H., Na, M. K., Kim, J. A., \& Lee, S. H. (2013). Phenolic glycosides from Lindera obtusiloba and their anti-allergic inflammatory activities. Natural Product Communications, 8(2), 181-182.
Cuendet, M., Oteham, C. P., Moon, R. C., \& Pezzuto, J. M. (2006). Quinone reductase induction as a biomarker for cancer chemoprevention. Journal of Natural Products, 69(3), 460-463.

Di Giovanni, S., Borloz, A., Urbain, A., Marston, A., Hostettmann, K., Carrupt, P. A., \& Reist, M. (2008). In vitro screening assays to identify natural or synthetic acetylcholinesterase inhibitors: Thin layer chromatography versus microplate methods. European Journal of Pharmaceutical Sciences, 33(2), 109-119.

Ding, Y., Liang, C., Nguyen, H. T., Choi, E. M., Kim, J. A., \& Kim, Y. H. (2010). Chemical constituents from Acer mandshuricum and their effects on the function of osteoblastic MC3T3-E1 cells. Bulletin of the Korean Chemical Society, 31(4), 929-933.

Ellman, G. L., Courtney, K. D., Andres, V., \& Featherstone, R. M. (1961). A new and rapid colorimetric determination of acetylcholinesterase activity. Biochemical Pharmacology, 7(2), 88-95.

Foy, C. J., Passmore, A. P., Vahidassr, M. D., Young, I. S., \& Lawson, J. T. (1999). Plasma chain-breaking antioxidants in Alzheimer's disease, vascular dementia and Parkinson's disease. QJM: An International Journal of Medicine, 92(1), 39-45.

Galvao, M. D., Narain, N., dos Santos, M. D. P., \& Nunes, M. L. (2011). Volatile compounds and descriptive odor attributes in umbu (Spondias tuberosa) fruits during maturation. Food Research International, 44(7), 1919-1926.

Giacomelli, E., Bertrand, S., Nievergelt, A., Zwick, V., Simoes-Pires, C., Marcourt, L., Rivara-Minten, E., Cuendet, M., Bisio, A., \& Wolfender, J. L. (2013). Cancer chemopreventive diterpenes from Salvia corrugata. Phytochemistry, 96, 257-264.

Gills, J. J., Jeffery, E. H., Matusheski, N. V., Moon, R. C., Lantvit, D. D., \& Pezzuto, J. M. (2006). Sulforaphane prevents mouse skin tumorigenesis during the stage of promotion. Cancer Letters, 236(1), 72-79.

Goncalves, A. E. D. S., Lajolo, F. M., \& Genovese, M. I. (2010). Chemical composition and antioxidant/antidiabetic potential of Brazilian native fruits and commercial frozen pulps. Journal of Agricultural and Food Chemistry, 58(8), 4666-4674.

Houghton, P. J., Ren, Y. H., \& Howes, M. J. (2006). Acetylcholinesterase inhibitors from plants and fungi. Natural Product Reports, 23(2), 181-199.

Huang, D. J., Ou, B. X., Hampsch-Woodill, M., Flanagan, J. A., \& Prior, R. L. (2002). High-throughput assay of oxygen radical absorbance capacity (ORAC) using a multichannel liquid handling system coupled with a microplate fluorescence reader in 96-well format. Journal of Agricultural and Food Chemistry, 50(16), 4437-4444.

Huang, D. J., Ou, B. X., \& Prior, R. L. (2005). The chemistry behind antioxidant capacity assays. Journal of Agricultural and Food Chemistry, 53(6), 1841-1856.

Kang, Y. H., \& Pezzuto, J. M. (2004). Induction of quinone reductase as a primary screen for natural product anticarcinogens. Methods in Enzymology, 382, 380-414.

Kubo, I., Kim, M., Naya, K., Komatsu, S., Yamagiwa, Y., Ohashi, K., Sakamoto, Y., Hirakawa, S., \& Kamikawa, T. (1987). Prostaglandin synthetase inhibitors from the African medicinal plant Ozoroa mucronata. Chemistry Letters, 16(6), 1101-1104.

Kulisic-Bilusic, T., Katalinic, V., Dragovic-Uzelac, V., Ljubenkov, I., Krisko, A., Dejanovic, B., Jukic, M., Politeo, O., Pifat, G., \& Milos, M. (2008). Antioxidant and acetylcholinesterase inhibiting activity of several aqueous tea infusions in vitro. Food Technology and Biotechnology, 46(4), 368-375.

Maia, G. A., Sousa, P. H. M., Lima, A. S., Carvalho, J. M., \& Figueiredo, R. W. (2009). Processamento de frutas tropicais. Fortaleza: UFC.

Mammela, P., Savolainen, H., Lindroos, L., Kangas, J., \& Vartiainen, T. (2000). Analysis of oak tannins by liquid chromatographyelectrospray ionisation mass spectrometry. Journal of Chromatography A, 891(1), 75-83. 
Mukherjee, P. K., Kumar, V., Mal, M., \& Houghton, P. J. (2007). Acetylcholinesterase inhibitors from plants. Phytomedicine, 14(4), 289-300.

Muller, L., Frohlich, K., \& Bohm, V. (2011). Comparative antioxidant activities of carotenoids measured by ferric reducing antioxidant power (FRAP), ABTS bleaching assay (alpha TEAC), DPPH assay and peroxyl radical scavenging assay. Food Chemistry, 129(1), 139-148.

Narain, N., Bora, P. S., Holschuh, H. J., \& Vasconcelos, M. A. D. (1992). Variation in physical and chemical-composition during maturation of umbu (Spondias tuberosa) fruits. Food Chemistry, 44(4), 255-259.

Omena, C. M. B., Valentim, I. B., Guedes, G. D., Rabelo, L. A., Mano, C. M., Bechara, E. J. H., Sawaya, A. C. H. F., Trevisan, M. T. S., da Costa, J. G., Ferreira, R. C. S., Sant'Ana, A. E. G., \& Goulart, M. O. F. (2012). Antioxidant, anti-acetylcholinesterase and cytotoxic activities of ethanol extracts of peel, pulp and seeds of exotic Brazilian fruits: Antioxidant, anti-acetylcholinesterase and cytotoxic activities in fruits. Food Research International, 49(1), 334-344.

Polasek, J., Queiroz, E. F., Marcourt, L., Meligova, A. K., Halabalaki, M., Skaltsounis, A. L., Alexis, M. N., Prajogo, B., Wolfender, J. L., \& Hostettmann, K. (2013). Peltogynoids and 2-phenoxychromones from Peltophorum pterocarpum and evaluation of their estrogenic activity. Planta Medica, 79(6), 480-486.

Re, R., Pellegrini, N., Proteggente, A., Pannala, A., Yang, M., \& Rice-Evans, C. (1999). Antioxidant activity applying an improved ABTS radical cation decolorization assay. Free Radical Biology and Medicine, 26(9-10), 1231-1237.

Rufino, M. D. M., Alves, R. E., de Brito, E. S., Perez-Jimenez, J., Saura-Calixto, F., \& Mancini, J. (2010). Bioactive compounds and antioxidant capacities of 18 non-traditional tropical fruits from Brazil. Food Chemistry, 121(4), 996-1002.
Song, L. L., Kosmeder, J. W., 2nd, Lee, S. K., Gerhauser, C., Lantvit, D., Moon, R. C., Moriarty, R. M., \& Pezzuto, J. M. (1999). Cancer chemopreventive activity mediated by 4'-bromoflavone, a potent inducer of phase II detoxification enzymes. Cancer Research, 59(3), 578-585.

Steinmetz, K. A., \& Potter, J. D. (1996). Vegetables, fruit, and cancer prevention: A review. Journal of the American Dietetic Association, 96(10), 1027-1039.

Tadic, V. M., Dobric, S., Markovic, G. M., Dordevic, S. M., Arsic, I. A., Menkovic, N. R., \& Stevic, T. (2008). Anti-inflammatory, gastroprotective, free-radical-scavenging, and antimicrobial activities of hawthorn berries ethanol extract. Journal of Agricultural Food and Chemistry, 56(17), 7700-7709.

Valko, M., Leibfritz, D., Moncol, J., Cronin, M. T. D., Mazur, M., \& Telser, J. (2007). Free radicals and antioxidants in normal physiological functions and human disease. International Journal of Biochemistry \& Cell Biology, 39(1), 44-84.

Viegas, C., Silva, D. H. S., Pivatto, M., de Rezende, A., CastroGamboa, I., Bolzani, V. S., \& Nair, M. G. (2007). Lipoperoxidation and cyclooxygenase enzyme inhibitory piperidine alkaloids from Cassia spectabilis green fruits. Journal of Natural Products, 70(12), 2026-2028.

Wada, H., Murakami, T., Tanaka, N., Nakamura, M., Saiki, Y., \& Chen, C. M. (1986). Chemical and chemotaxonomical studies of filices. 66. Chemical studies on the constituents of Pseudocyclosorus subochthodes Ching and Pseudocyclosorus Esquirolii Ching. Yakugaku Zasshi: Journal of the Pharmaceutical Society of Japan, 106(11), 989-994.

Zeraik, M. L., Serteyn, D., Deby-Dupont, G., Wauters, J. N., Tits, M., Yariwake, J. H., Angenot, L., \& Franck, T. (2011). Evaluation of the antioxidant activity of passion fruit (Passiflora edulis and Passiflora alata) extracts on stimulated neutrophils and myeloperoxidase activity assays. Food Chemistry, 128(2), 259265. 